\title{
Situating Indigenous knowledge for resilience in fire-dependent social- ecological systems
}

\author{
$\underline{\text { Kelsey Copes-Gerbitz }}^{1}$, Shannon M. Hagerman ${ }^{1}$ and Lori D. Daniels ${ }^{1}$
}

\begin{abstract}
With the growing challenge of addressing modern fire risk, land managers and researchers are increasingly looking to Indigenous knowledge as a primary source of information for enabling resilience of fire-dependent social-ecological systems (SES). Although this is an important step forward for recognizing the contribution of Indigenous peoples to fire-dependent landscapes, current SES research in fire contexts views knowledge as detached from power, reflecting a critique in SES resilience research more broadly. Integrating Indigenous knowledge into dominant colonial management paradigms (such as "command and control" management of fire) without attention to these power asymmetries will lead to inequitable solutions to modern wildfire challenges. To address this gap, we employ the concept of situated resilience - which views knowledge as a process contextualized within power dynamics-to a case study of a fire-dependent SES in the traditional territory of the T'exelc (Williams Lake First Nation), in the land now known as British Columbia, Canada. Through a "collaborative experiment" research design that incorporated iterative, long-term, ethical research relationships guiding knowledge co-production in forest walks, we engaged with T'exelc Elders, archaeologists, and forest managers to explore the context of Indigenous fire knowledge and situate Indigenous definitions of resilience in future forest management. Results indicate that for the T'exelc, the intentional use of fire to support their livelihoods was lost due to colonialism. This colonial context disrupted place-based, intergenerational knowledge transmission and resulted in forest management devoid of respect. However, employing the concept of situated resilience moved us beyond a preoccupation with the content of fire knowledge toward actively shifting the colonial context in which T'exelc knowledge was embedded. Through our collaborative experiment, and the trust built among T'exelc Elders, archaeologists, and forest managers, future forest management will more directly work to restore intergenerational knowledge exchange and respect and situate Indigenous-led resilience to modern wildfire challenges.
\end{abstract}

Key Words: fire; Indigenous fire stewardship; Indigenous knowledge; resilience; social-ecological systems

\section{INTRODUCTION}

Indigenous peoples coexisted with and stewarded fire for millennia (Lewis 1982, Bowman et al. 2011, Huffman 2013, Lake and Christianson 2019, Smith and Mistry 2021). Although there are many examples of Indigenous fire stewardship that continues to adapt to modern contexts (Lake and Christianson 2019), the ongoing impacts of colonialism and "command and control" approaches to fire governance (Holling and Meffe 1996) have often displaced and marginalized Indigenous peoples and suppressed their stewardship practices (Eriksen and Hankins 2014, Christianson 2015). Furthermore, against the backdrop of recent global mega-fires that have significantly impacted human livelihoods (Stephens et al. 2014, Smith et al. 2016), many Indigenous communities face systematic biases against their needs, values, and concerns and are often at higher risk during modern wildfire events (Christianson 2015, McGee et al. 2019). Understanding and addressing these inequalities in the context of current wildfire challenges has emerged as a key research need (Sankey 2018) and one that can be aided by taking an integrated social-ecological systems (SES) perspective (Berkes and Folke 1998, Liu et al. 2007, Ostrom 2009).

From an SES perspective, social and ecological systems are complex and have dynamic feedbacks across multiple spatial and temporal scales (Liu et al. 2007, McGinnis and Ostrom 2014). Importantly, the SES perspective views environmental challenges, such as wildfire, as inextricably linked to underlying social and political contexts (Berkes and Folke 1998). Although fire has long been understood as an ecological process (Bowman et al. 2009, Krebs et al. 2010), the SES perspective demonstrates that fire interacts with and is dependent on social values and decision making (Bowman et al. 2011, Moritz et al. 2014, Spies et al. 2014, Fischer et al. 2016, Smith et al. 2016). For example, some wildfire SES scholars have mapped modern fire-dependent SES to illustrate the multiple levels of governance (from local to national) that influence the fire challenge (Moritz et al. 2014, Spies et al. 2014, Fischer et al. 2016), whereas others have described the extent to which people interacted with and shaped fire through time (Bowman et al. 2011, Roos et al. 2014).

In addition, the concept of resilience is often applied to environmental challenges to better understand and navigate uncertainty and complexity (Berkes et al. 2003, Folke et al. 2010, Binder et al. 2011, Folke 2016). Several fire SES scholars argue that enabling resilience in fire-dependent landscapes requires context-specific solutions and locally relevant desired futures (Stephens et al. 2013, Moritz et al. 2014, Higuera et al. 2019) developed through participatory processes (Fischer et al. 2016). These processes benefit from stronger social networks that increase capacity (Spies et al. 2014, Fischer et al. 2016) and overcome knowledge silos (Smith et al. 2016). Critically, these scholars underscore the key role of local actors, including Indigenous peoples, in achieving fire-resilient communities (Moritz et al. 2014, Smith et al. 2016). These insights are an important foundation for bridging the research silos of social vs. natural science (Smith et al. 2016) and providing tangible pathways for applying resilience concepts to fire governance (Steelman 2016, McWethy et al. 2019). However, what has not yet been addressed in the context of wildfire are some of the shortcomings of an SES resilience perspective, including the 
unequal attention to the social dimensions of resilience and the power inherent in different forms of knowledge (e.g., Indigenous, Western science, practitioner).

The gap in analytical attention to the role of knowledge in fire SES research is a point of contention within SES research more broadly. Critiques of SES resilience center on the tendency to inadequately recognize, understand, and incorporate social dimensions of resilience (Adger 2000, Brown 2014). Specifically, past SES research has tended to view knowledge as apolitical and detached from power-ignoring power asymmetries between different sources of knowledge that may perceive resilience differently (Cote and Nightingale 2012, Brown 2014). Although resilience scholars have long valued multiple forms of knowledge (including Indigenous) for developing solutions to environmental challenges (Walker and Salt 2006, Berkes 2009), Western science has largely focused on the "content" of the knowledge rather than the political "context" in which it is embedded (Cote and Nightingale 2012, Ingalls and Stedman 2016). From a Western science perspective, the content of knowledge is viewed as factual observations or data about an ecological system of interest (Pierotti and Wildcat 2000, Usher 2000, Houde 2007). In contrast, the context of knowledge includes the social, cultural, and political factors that drive dynamics in a SES (Berkes and Folke 1998), including decisionmaking systems, knowledge-transmission processes, cosmology, and cultural identity (Turner et al. 2000, Houde 2007, Bohensky and Maru 2011). Viewing the content of knowledge as static, extractable data can lead to the "knowledge integration trap," whereby knowledge that is less connected to structures of power is subsumed into the dominant paradigm (e.g., command and control) without addressing the power asymmetries between knowledge systems (Agrawal 1995, Nadasdy 1999, Bohensky and Maru 2011). Treating knowledge as apolitical can lead to prescriptive management approaches that perpetuate power inequalities between different knowledge holders (Davidson-Hunt and O'Flaherty 2007, Pelai et al. 2021) and may result in inequitable solutions guided by assumptions of what knowledge is appropriate for resilience (Cote and Nightingale 2012).

In the fire context, for example, the Western science community is beginning to acknowledge the contribution of Indigenous peoples to fire-dependent landscapes and incorporate Indigenous fire knowledge (Huffman 2013, Christianson 2015, Lake et al. 2018). In many cases, however, these efforts are solely focused on integrating the content of Indigenous fire stewardship that is easily translated into Western science frameworks, such as objectives of fire use (Boyd 1999) and biophysical categories of fire knowledge, including geology, topography, and soils; vegetation and fuels; weather; fire behavior; fire operations; and fire effects (Huffman 2013). From an Indigenous fire stewardship perspective, however, the context of knowledge includes spiritual elements (Turner et al. 2000, Miller and Davidson-Hunt 2013), intergenerational processes of knowledge transmission, decision making and adaptation (Turner et al. 2000, Huffman 2013, Lake and Christianson 2019), and the political and governance settings within which Indigenous fire stewardship exists (Eriksen 2007, Martínez-Torres et al. 2016, Rodríguez et al. 2018). Despite recommendations from Indigenous fire stewards and supporting researchers to promote more meaningful engagement with Indigenous communities through Indigenous-led research and practice (Miller and Davidson-Hunt 2013, Lake et al. 2017), current SES resilience literature around fire has yet to adequately conceptualize and incorporate the context of Indigenous fire stewardship. Failure to address this shortfall will continue to narrowly define what constitutes appropriate knowledge in an SES by focusing only on the content and discounting Indigenous perspectives of resilience in developing solutions to the modern fire challenge (Eriksen and Hankins 2014, Christianson 2015).

The concept of "situated resilience" provides a potential way forward for addressing some of the shortfalls outlined. A situated resilience approach centers the context of knowledge and stresses that knowledge is fundamentally changed if it is viewed solely as content and extracted from the broader social, cultural, and political contexts within which it sits (Agrawal 1995, Cote and Nightingale 2012). Proponents argue that situating resilience challenges researchers and managers to move beyond a preoccupation with collecting the right data, to acknowledging knowledge as contested and embedded within asymmetric structures of power (Cote and Nightingale 2012). Situating resilience is fundamental for addressing the question of whose resilience is being enabled and how it may affect others (Cote and Nightingale 2012, Brown 2014, Cretney 2014, Cutter 2016). In these ways, employing situated resilience may help address the existing gap in the fire SES resilience literature with regard to Indigenous perspectives (Adger 2000, Cote and Nightingale 2012). Moreover, this concept aligns with Indigenous epistemologies by embracing the context of knowledge creation (Smith 2012) as fundamental to understanding the relationship between people, fire, and the land (Miller and Davidson-Hunt 2013, Lake and Christianson 2019) than more conventional (or Western scientific institutional) approaches to resilience (Cote and Nightingale 2012).

The aim of this study is to examine the context of Indigenous knowledge in a fire-dependent SES by utilizing the concept of "situated resilience." Specifically, this study applies "situated resilience" to a case study in a portion of the ancestral territory of an Indigenous (First Nation) community in the land now known as British Columbia, Canada, where contestations over land ownership are ongoing (Borrows 2017, Wilson 2019) and modern wildfires are increasingly threatening livelihoods (Abbott and Chapman 2018, Hanes et al. 2019). We address two research questions: (1) What is the context of fire knowledge for the T'exelc (Williams Lake First Nation)? (2) How can understanding this context help guide decision making for future forest management? We demonstrate that our research process helped shift the context of T'exlec knowledge and situate Indigenous definitions of resilience in future forest management. This analysis illuminates a set of novel recommendations for managers and researchers seeking to learn from, work with, and support Indigenous definitions of resilience as they relate to wildfire specifically and forest management more broadly.

\section{Research Context}

The T'exelc are members of the Northern Secwépemc te Qelmucw (Northern Shuswap Tribal Council) whose ancestral territory is within the modern boundaries of the Cariboo Region in the dry forest ecosystems in the interior of British Columbia, Canada. Across British Columbia, including in the Secwepemcúl'ecw (the ancestral territory of the Secwépemc), Indigenous fire stewardship historically achieved a variety of cultural and 
ecological objectives, including maintaining food and medicinal species and reducing wildfire risk to communities through practices such as intentional landscape burns (Gottesfeld 1994, Turner et al. 2000, Ignace et al. 2016, Lewis et al. 2018). Although some of these practices continue today in an adapted form (Lewis et al. 2018, Lake and Christianson 2019), the privileging of nonIndigenous knowledge about fire in the 21 st century through command and control environmental governance has resulted in colonial policies of fire suppression actively limiting Indigenous fire stewardship (Holling and Meffe 1996, Lake et al. 2018, Nikolakis and Roberts 2020). The extent to which Indigenous fire stewardship survives within individual communities is inherently linked to the historical and modern social and political dynamics - particularly the ways and extent to which colonial land governance systems historically superseded Indigenous land governance systems and continue to permeate modern landscape governance (Lake et al. 2018, Lake and Christianson 2019, Nikolakis and Roberts 2020). Across most of British Columbia, treaties with Indigenous peoples were never negotiated before the province was officially incorporated into Canada in 1871, and legal contestations over sovereignty continue today on ca. $95 \%$ of the land area (Borrows 2017, Wilson 2019).

In 2014, a portion of the T'exelc ancestral territory was incorporated into the Ne Sextsine (Flat Rock) portion of the Williams Lake Community Forest (hereafter Community Forest; Fig. 1), a 5900-ha area of forest and grassland co-managed by the T'exelc and the City of Williams Lake. Although its long-term tenure agreement as a community forest dictates that it must be managed for "social, ecological, and economic sustainability" (British Columbia Community Forest Association (BCCFA) 2020), community safety from wildfire is a key mandate driving land-management decisions given its location in the wildlandurban interface adjacent to major population centers. During the wildfire season of 2017, 1.2 million ha burned across British Columbia. This was the largest area burned in the provincial written record (although surpassed in 2018), with much of the impact centered in the Cariboo Region. The T'exelc were one of 26 First Nations communities evacuated during the 2017 wildfires (Abbott and Chapman 2018), and the nearest fire came within $200 \mathrm{~m}$ of $\mathrm{Ne}$ Sextsine. In response to the unprecedented impacts of the 2017 wildfire season, a provincial-level review in consultation with fire-affected communities provided recommendations to mitigate future negative impacts. Of the 108 recommendations made, 40 of these aimed to increase the input and decision-making power of Indigenous peoples (Abbott and Chapman 2018). In keeping with these recommendations, this research seeks to empower Indigenous communities by engaging in a collaborative process (described below) with research partners including the T'exelc Elders, archaeologists, and community forest managers to generate insights for future management of Ne Sextsine.

\section{METHODOLOGY}

\section{Approach}

We used an iterative, reflexive, collaborative approach to be responsive to our research partners' needs and to meaningfully address the research questions for which support and recognition of different forms of knowledge are critical. Our approach is informed by principles from community-based participatory research (Datta et al. 2015) and collaborative and decolonizing methodologies (Smith 2012, Velasquez Runk 2014). In particular, these principles include ethical protocols for engagement with Indigenous communities (Smith 2012) that include long-term engagement, reciprocity, and flexibility of the research design. Validity strategies (Creswell 2013) were applied to address researcher positionality and bias (Sultana 2007) such as prolonged engagement (Smith 2012), triangulation through iterative data collection, and analyses with collaborators (Tengö et al. 2014), and a focus on place-based relationality (Datta et al. 2015) and land-based learning (Simpson 2017). Importantly, our approach also incorporates transformative and pragmatic paradigms (Creswell 2014) that aim to empower Indigenous perspectives (Datta et al. 2015) that are under-represented in wildfire research and management spheres (Christianson 2015, Neale et al. 2019).

Fig. 1. Modern boundary of Ne Sextsine, a portion of the Williams Lake Community Forest within the ancestral territory of the T'exelc.

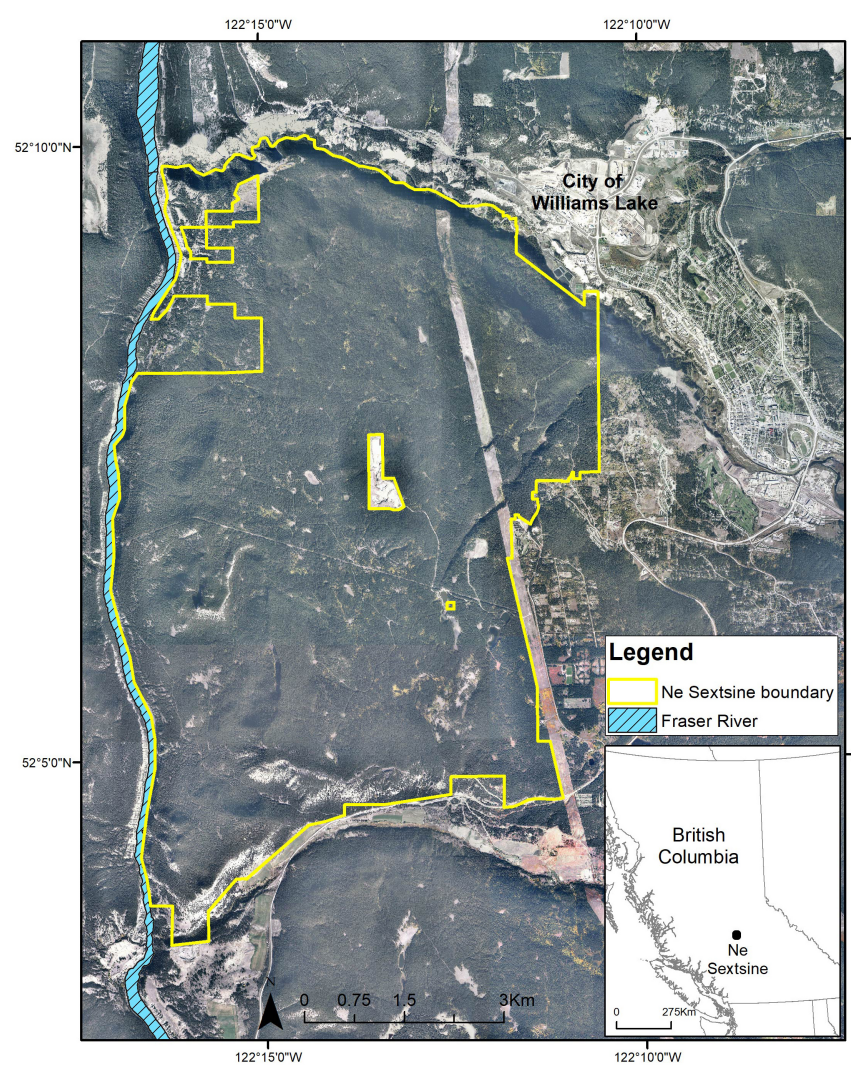

Our approach embraces the idea of collaborative research as a "decolonizing experiment," through which different worldviews can be explored to help inform the development of alternative futures (Neale et al. 2019). By recognizing power and knowledge as endogenous processes embedded within a unique context (Davidson-Hunt and O'Flaherty 2007, Cote and Nightingale 2012, Ban et al. 2018), our approach provides the methodological and operational link to the concept of "situated resilience." 
Likewise, it provides space for experimentation and learning, which are fundamental for maintaining the inherent validity of different forms of knowledge (Sultana 2007, Stone-Jovicich et al. 2018) and for encouraging epistemological transparency when working across worldviews (Blythe et al. 2017, Stone-Jovicich et al. 2018). For this research, we describe our broad approach as a "collaborative experiment" that incorporates reflexivity, learning, and long-term ethical engagement and responds directly to community needs, as informed by participatory and decolonizing methodologies.

Community partners were instrumental in identifying and determining appropriate protocols around data collection, ownership, and dissemination, including data collection through land-based forest walks with T'exelc Elders, data sharing with the Natural Resources and Treaty Departments of the Williams Lake First Nation, and appropriate dissemination methods including annual reports and community presentations. These design elements were ensured through the signing of a Memorandum of Understanding between the T'exelc Chief, the manager of the Community Forest, and researchers at the University of British Columbia in the early stages of the research. The research presented here reflects of the ongoing process of engagement since 2016, including two meetings with the T'exelc Chief and Council, six meetings with the T'exelc Elder Council, two Community Forest open-house meetings, and extensive guidance on the research design and results from representatives of the Williams Lake First Nation Natural Resources Department and managers of the Community Forest. The research process was initiated on request of a gatekeeper in 2016 who represented the interests of the T'exelc in the Community Forest. To support this engagement, the first author spent approximately 9 months in the study area directly engaged with the research partners.

In working with Indigenous communities, clarity of researcher positionality and bias is central to interpreting the validity of the research process (Sultana 2007). The researchers are nonIndigenous or "semé7" (white person) settlers to British Columbia, with the lead researcher (K. Copes-Gerbitz) originally from Hawaii and L. D. Daniels and S. M. Hagerman from other parts of Canada. L. D. Daniels has worked with Indigenous and non-Indigenous communities in this area of British Columbia since 2013 in the context of fire research, and this collaboration is a continuation of the relationships built through that time with an early advocate of the research (a non-Indigenous partner from the Williams Lake Community Forest) acting as a preliminary "gatekeeper" to facilitate the development of an ethical research relationship (Creswell 2013). Recognizing our identities as external to the community, reflexivity ensured that we first and foremost maintained accountability to the community needs (Smith 2012, Velasquez Runk 2014, Datta et al. 2015).

\section{Data Collection and Analysis}

Through the process detailed above, it was collectively decided that group forest walks with the T'exelc Elders would be the most appropriate data collection strategy. Forest walks were designed in the spirit of the collaborative experiment, in which all people present shared their knowledge of Ne Sextsine and wildfire in an effort to co-produce a deeper, place-based understanding of the context of T'exelc fire knowledge and visions for future forest management. These forest walks were offered to all attendees of the T'exelc Elder Council meetings and organized collectively to maximize participation. We recognize, however, that the attendees' perspectives are likely not representative of all T'exelc Elders nor of all T'exelcemc (people of the T'exelc), and thus we focus our analyses on learning directly from the Elders that did attend.

Two forest walks averaging 3 ha each were undertaken in September 2018 and June 2019, during which a total of eight T'exelc Elders, two Community Forest managers, four archaeologists, and three researchers attended and contributed. The aim and guiding topics for the forest walks were to share experiences, perspectives, and knowledge about the history of the land, including (but not limited to) fire and visions for future forest management. Forest walks were audio-recorded with consent and transcribed for a total of 40 pages of transcription. Transcripts were analyzed in NVivo (v. 12.6.0 2020) software using iterative and inductive coding to identify key themes "grounded" in the data from the participants' perspectives (Charmaz 2006). Identified themes were triangulated with a close reading of oral histories documented in 29 interviews ( 24 in the 1990s and five in 2012) conducted as part of traditional use studies undertaken by the Williams Lake First Nation with T'exelc Elders (not available for coding because of data confidentiality), maps of known archaeological and cultural heritage sites (as provided and interpreted by the archaeologist), archival documents of the history of the T'exelc and settlers (available at the Museum of the Cariboo Chilcotin), tree-ring based fire histories developed by K. Copes-Gerbitz (from a complementary portion of their PhD dissertation research), and through iterative feedback from research partners.

\section{RESULTS}

This collaborative experiment revealed two key findings around the context of T'exelc fire knowledge: (1) the intentional use of fire is today considered a "lost practice" that was disrupted by colonialism and (2) future forest management should center on restoring the context of T'exelc knowledge more broadly, which is rooted in respect and achieved through place-based, intergenerational knowledge exchange. Through this analysis, we demonstrate how the concept of situated resilience can be employed to guide future forest management by focusing on the context of Indigenous knowledge within a fire SES. Quotes are attributed to Elders by name where possible following appropriate knowledge protocols outlined in the Memorandum of Understanding and with the expressed permission of individuals.

\section{A "Lost Practice" Disrupted by Colonialism}

In the early stages of the collaborative experiment, it was clear that intentional burning by the T'exelcemc (the people of T'exelc) was not an active practice within the boundaries of Ne Sextsine. However, among the eight Elders who attended the forest tours, several remember hearing stories from their elder family members about the use of intentional burning in the Secwepemcúl'ecw by previous generations:
[My aunt] would talk about they'd burn. And then when they were talking about where they're going to go, the one who knew [about fire] would tell the Chief "Well no we can't go there, we just burnt" or "Maybe we should go there because last year, or whenever, we burnt there so it 
should be good now." So they never overharvested...an area. [Elder Estkwelálnik]

That's something I really don't know anything about... like normally it was the...horse people... and they were out...on the range... hunting or whatever. And they would be the ones that would...do those kind of things [like burning ]...I had an uncle that possibly would have done it. [Elder Jean William]

When describing the objectives for which intentional burning may have been used, Elder Estkwelálnik spoke of its importance for maintaining desired landscape conditions and associated food species. For example, this Elder understood that "in some places, raspberries will come back stronger" after the right kind of fire. Elder Estkwelálnik went on to describe the right kind of fire in contrast to the recent (2017) fires, which burned an area that Elders Jean William and Estkwelálnik used to visit to teach the youth about important cultural plants: "it has burned so hard the ground was going to be useless for a long time." This content of fire knowledge (e.g., objectives for burning) as beneficial to food and medicinal species is highlighted as a conclusion of the 1998 Final Report for the Williams Lake Indian Band Traditional Use Study (Traditional Land Use Team 1998):

Natural conservation is practiced among people who go out on the land. If an area can no longer support an abundance of certain plants or wildlife, T'exelc members usually leave it alone for a few years so it can replenish itself. Other natural occurrences are taken into account for traditional gathering such as burn areas. These are known for good berry picking areas three years after the burn has occurred. (p. 27)

In addition to conveying the benefits of fire, Elders Jean William and Estkwelálnik also described how the landscape looked without intentional fire-noting that the context of fire knowledge had changed through time, from being an active practice supporting their livelihoods to today being a "lost practice" [Elder Estkwelálnik]. Elder Estkwelálnik reflected that part of the forest in the Secwepemcúl'ecw had gotten "too thick," such that when they visited 30 years ago they had to tie "markers on trees" so they could find their way through the forest. In this "too thick" state, Elder Estkwelálnik was told that the forest and associated plant species of importance were "no good because... they just let it grow, they haven't burnt it." At Ne Sextsine specifically, Elder Jean William noted that the land adjacent to the main travel route to her summer fishing camp was also thicker with trees than when she was last at the site over 30 years ago. Supporting Elder Jean William's recollections, this area was demarcated through a separate ecological study as an area of historical grassland and is currently the site of grassland restoration (Williams Lake Community Forest Limited Partnership 2015). The fact that only two Elders (Jean William and Estkwelálnik) of eight had memories of the content (in this case, objectives) of intentional fire further speaks to how it had become a "lost practice" among the T'exelcmec, which was largely attributed to the context of historical and ongoing colonial impacts on their community.

The colonial context in which the T'exelc fire knowledge had become "lost" was attributed to multiple converging impacts: policies of pre-emption which allowed settlers but not Indigenous peoples to acquire "rights" to land for settlement and agriculture (ca. 1859), the smallpox epidemic, which is estimated to have killed up to two-thirds of the Indigenous population in British Columbia (1860s), and the reservation and residential school systems implemented by the Indian Act, which forcibly removed people from their land (1876) (Truth and Reconciliation Commission 2015, Ignace and Ignace 2019). Although these were historical events, Indigenous peoples in British Columbia and Canada continue to face ongoing animosity and racism as a result of systematic colonial structures that still exist (e.g., the Indian Act) despite stated intentions to address these colonial impacts through reconciliation (Fisher and Lundberg 2015, Ignace and Ignace 2019, Caverley et al. 2020). As a result of this colonial context, place-based knowledge transmission within their traditional territory, including Ne Sextsine, was disrupted and, in many cases, silenced - which fundamentally altered the current T'exelc Elders' lived experiences with fire stewardship.

There were several examples of Elders who had memories of both intentional burning and other interactions with fire in a colonial context. For example, some Elders recalled intentional burning from when they were children (about 40-60 years ago), but only within their reserve lands: "I remember that because...they'd be burning on the reserve and they'd...make ditches for runoff" [Elder Estkwelálnik]. Similarly, Elder Millie Emile remembered the burning around the reserve primarily occurring during the springtime. In another example, Elder 7 spoke of their job as a firefighter during the "big fires in 1977"- - a job that was required by law (and therefore punitive) for able-bodied citizens should they be called upon in British Columbia at least until the 1970s. Elder 7 contrasted the "big fires in 1977" with those that occurred in 2017: "Here and in the Chilcotin [Region], just across the river, those [in 1977] were not big fires. I would say they were manageable, not like a couple years ago [2017]. Not that big fire." In the 2012 Traditional Use Study, two different Elders also spoke of their experiences as firefighters undertaking prescribed burns in the Secwepemcúl'ecw. Together, these Elders' lived experiences of firefighting and burning around their reserve collectively represent fire knowledge in a colonial context once the intentional use of fire had become a "lost practice" in the Secwepemcúl'ecw.

Colonial contexts disrupted more than the intergenerational transmission of fire knowledge across their traditional territory historically, it also disrupted all place-based practices and continues to do so today. At Ne Sextsine specifically, there is extensive archaeological evidence of winter village sites and many oral histories describing it as an important summer fishing camp, but these activities do not continue today even though Ne Sextsine is technically co-managed by the T'exelc. Reflecting on why this may be, Elder Estkwelálnik said:

I think is because of all the pre-emptions...like when I used to go out with [my family] and we'd go berry picking... and we'd run into places and [my mom] would get so upset...there's no trespassing, there's fences and my mother just got to a point where she said "I don't want to do it anymore". Everywhere you go... there's fences... you can't go there anymore. 
Although several Elders remembered having a meaningful trade relationship with a local settler whose private property was adjacent to Ne Sextsine, their relationship soured to the point that they had not visited in 20 or 30 years:

\section{...because the gate [allowing entrance to their fishing camps 7 started to be locked... And then we had to ask for permission to come... basically we just lost the fight. We didn't want to have to be hassled. I've had a really bad experience trying to get to...[Ne Sextsine] [Elder Jean William].}

Of the Elders who contributed to the forest walks, only the older generation (in their late 70s and early $80 \mathrm{~s}$ ) had memories of life at $\mathrm{Ne}$ Sextsine. These lived experiences were critical times of learning by practice in their youth through knowledge transmission from their elders; one Elder [7] reflected that they knew "a century plus" of tradition because "we were there, we saw it, we were with [our grandparents]." The importance of the context of this knowledge, transmitted through place-based practice, is exemplified by this story from Elder Virginia Gilbert remembering their childhood at Flat Rock:

\section{I wasn't allowed to go down the river until I was about 12. And when I went down the river I had to help pack salmon back up... So that was one of my teachings, was when I went down there I had to help. Pretty neat.}

The younger generation of Elders, in contrast, had often only heard stories of Ne Sextsine because of the colonial context in which their place-based knowledge could exist. Elder Estkwelálnik, for example, was told by an aunt about culturally modified trees that marked primary travel corridors but said "I didn't understand what she was saying" because Elder Estkwelálnik had never seen one - a clear example of divorcing the content of knowledge (e.g., culturally modified trees) from the context (the place in their traditional territory where they existed). These marker trees are still visible at Ne Sextsine today, and upon seeing one during the forest walk this Elder remarked "this is just unbelievable. [I remember] hearing stories about these when we would go hunting...they know their directions from these, but I never seen it." These quotes speak to the importance of access to place for providing context for knowledge transmission between generations. A lack of access to place was also described in the Final Report for the Williams Lake Indian Band Traditional Use Study (Traditional Land Use Team 1998), which found disparities in land-based knowledge between different generations and attributed these disparities to colonial contexts: "Older members in the community had a wider use of the land than the younger members. This is because of the restrictions placed on the land." (p. 26)

The implications of this restricted access to their land-and the colonial context more broadly - is exemplified by the late Chief William's (Chief of the Williams Lake First Nation) letter to a local newspaper published in 1879 ("An astonishing state of things at Williams Lake," 1879), the same year he traveled to begin treaty talks with the colonial government of British Columbia:

The land on which my people lived for five hundred years was taken by a white man; he has piles of wheat and herds of cattle. We have nothing - not an acre... Any white man can take three hundred and twenty acres of our land and the Indian dare not touch an acre. Her Majesty sent me a coat, two ploughs and some turnip seed. The coat will not keep away the hunger; the ploughs are idle and the seed is useless because we have no land... The whites have taken all the salmon and all the land and my people will not starve in peace. Good friends to the Indian say that "her Majesty loves her Indian subjects and will do justice." Justice is no use for a dead Indian. (Chief William 1879)

(Re)activating Place-based Knowledge through Our

\section{Collaborative Experiment}

Despite the colonial context that disrupted knowledge transmission, our collaborative experiment and forest walks helped create a new context for (re)activating the Elders' knowledge - one that illuminated the Elders' enduring connection to Ne Sextsine and provided a pathway for this new context of knowledge to guide future forest management. Specifically, the Elders' enduring connection to place was demonstrated through stories about important plant species and their commitment to upholding respect for the land and their ancestors. To uphold this enduring connection to place in future forest management, the collaborative experiment helped facilitate a trust-building process between T'exelc Elders, archaeologists, community forest managers, and researchers and provided a new context for situated resilience that contrasted colonial suppression of Indigenous knowledge.

Although the content of fire knowledge may have been lost, contextual knowledge of important practices (such as fishing and hunting), food and medicinal species endured. Reactivating these memories was stimulated by walking through the forest, questions from the archaeologists like "How would you catch the sturgeon?" (Courtney Lawrence), and photos of projectile points found within the broader T'exelc traditional territory. Elder Virginia Gilbert remembered "camping down there with [their] parents, and the men would fish mostly during the night, and [the] women we had to look after picking up the wood for the fire...and sometimes we'd be picking berries." This focus on berries for food, and plants in general for multiple uses, was a primary topic of conversation, with multiple Elders making note of specific plants or plant products visible during the forest walks that were important to their livelihoods (Table 1). Although these plants did not necessarily relate to fire knowledge (e.g., as fire-dependent species that were cultivated through intentional burning), they provide an important context for the knowledge that does endure. Elder Jean William, reflecting on her enduring connection to $\mathrm{Ne}$ Sextsine, spoke about all the ways the land supported their community:
Money wasn't a big thing back then. And that's why I say I was self-sustained because we lived on the land, we got our medicines from the land...food or medicines, technology... Where we were we had two springs, one for us that sustained us for our water, and the other spring sustained our horses... And so it looked after all of our needs.

Central to upholding this enduring knowledge was demonstrating respect for the land and the Elders' ancestors who were still present at $\mathrm{Ne}$ Sextsine. During both forest walks, we were among historical winter village sites, which encompass up to 35 individual dwellings [W. Spearing, WLFN Archaeologist, personal 
Table 1. The place-based context of T'exelc knowledge, including important plant and animal species supporting their livelihoods at Ne Sextsine.

\begin{tabular}{|c|c|c|c|}
\hline Common or "given" name(s) & Secwepemctsín name & Scientific name & Purpose discussed \\
\hline $\begin{array}{l}\text { Salmon - sockeye and "spring" } \\
\text { (Chinook) }\end{array}$ & Sqlélten & $\begin{array}{l}\text { Oncorhynchus nerka (sockeye) and } \\
\text { Oncorhynchus tshawytscha (spring) }\end{array}$ & $\begin{array}{l}\text { Food for individual family and community } \\
\text { (dried in preparation for the winter) }\end{array}$ \\
\hline Deer (mule deer) & Tsí & Odocoileus hemionus & Food \\
\hline Rocky Mountain “juniper” & Punllp & Juniperus scopulorum & $\begin{array}{l}\text { Funerals, berries for medicine, put in } \\
\text { boiling water for sweathouses }\end{array}$ \\
\hline Douglas-fir & $\begin{array}{l}\text { Qwéltsen (fir or pine boughs; } \\
\text { Púcwels (fir pitch) or tséqwelcken } \\
\text { (hard pitch on fir trees) }\end{array}$ & Pseudotsuga menziesii & $\begin{array}{l}\text { Boughs for mattresses } \\
\text { Pitch for medicine }\end{array}$ \\
\hline Silverweed & Cícel or cílcel & $\begin{array}{l}\text { Potentilla anserine syn. Argentina } \\
\text { anserina }\end{array}$ & $\begin{array}{l}\text { Roots for spaghetti (primarily from places } \\
\text { wetter than Ne Sextsine) }\end{array}$ \\
\hline Rose (unspecified) & & Rosa sp. & $\begin{array}{l}\text { Spiritual and medicinal purposes; put in } \\
\text { tea }\end{array}$ \\
\hline Yarrow, "chipmunk tail" & Qetsqets' uye7éllp & Achillea millefolium & Medicine \\
\hline Brittle prickly-pear cactus & Sekí7 & Opuntia fragilis & Food \\
\hline Saskatoon & $\begin{array}{l}\text { Speqpeq7úw̉I (Saskatoon berries) } \\
\text {-small to medium size bushes }\end{array}$ & Amelanchier alnifolia & Food \\
\hline $\begin{array}{l}\text { Snowberry ("ghost berry" or } \\
\text { waxberry) }\end{array}$ & Tpeqpqúqse 7 & Symphiocarpus alba & Medicine \\
\hline "Lowbush blueberry" & Sesép & Vaccinium scoparium & Food \\
\hline Chokecherry & $\begin{array}{l}\text { Tkwelse7éllp (tree), tekwlóse } 7 \\
\text { (berry) }\end{array}$ & Prunus virginiana & Food \\
\hline Soapberry & $\begin{array}{l}\text { Sxwesméllp (bush), Sxúsem } \\
\text { (berry) }\end{array}$ & Shepherdia canadensis & Medicine, food \\
\hline
\end{tabular}

communication]. These winter homes, also called pit houses or "c7ístkteñ" in Secwepemctsín (the Secwépemc language), were typically occupied from November to March; however, the last recorded occupation of village sites in Secwepemcúl'ecw was likely several generations prior to the Elders' memories [W. Spearing, WLFN Archaeologist, personal communication]. Nevertheless, the Elders exhibited deep respect for their ancestors through placing of tobacco and singing a song to honor them. Of placing the tobacco, Elder Estkwelálnik said, "They say when...you're coming here, they come around, the ancestors... That's why we're putting the tobacco down because we want them to know that we're thinking about them and we know that they're here." Elder Virginia Gilbert, who drummed and sang a song in Secwepemctsín along with four other Elders, said "I went four rounds of the four directions to call in the four spirits to come here to welcome our ancestors to be with us today." After this song, Elder 7 stated, "I have a great sense that they're still here with us today." These practices and quotes illustrate the ongoing reverence for their ancestors, which they also requested of the researchers and managers:

It's really, really important for people that are working... in archaeology, or doing any forestry work, [to] always remember that...our people have been here... And you always try to remember them in reverence... You can, do your practice anyway you know how. Just the reverence and respect that you have for them...Because our ancestors are here, they're watching us, they hear us. [Elder Jean William]

Discussions during the forest walks highlighted the importance of our collaborative experiment for helping to (re)activate this place-based knowledge and, perhaps more importantly, building trust among participants to create a new context for the Elders' place-based knowledge to guide the future of forest management. Reflecting on the management of $\mathrm{Ne}$ Sextsine prior to it becoming a Community Forest in 2014, several Elders were frustrated by the visible "cultural invasion" [Elder Jean William] or "cultural alteration" [Elder 7] by non-Indigenous peoples who had no respect for $\mathrm{Ne}$ Sextsine, exhibited in logging, bike trails, and snowmobile trails that cut through or were built upon the winter village sites. Elder Jean William continued to describe how the "cultural invasion" erased the context of their knowledge, focusing solely on the content through the process of "consultation" with Indigenous communities in British Columbia: "In the past, their maps were already made out, tons of work was already done, and you think, 'what I'm going to say now is not going to mean anything, it's already on paper.",

In contrast to the historical process of consultation described above, several Elders appreciated the opportunity provided through our collaborative experiment to engage and build trust with the community forest managers. When advocating for the Elders' preferred approach to forest management, Elder Jean William said to the community forest manager: "I guess it's just the awareness and how meaningful it still [is]... I think any [management] is acceptable if... you know the respect. And I think you gathered that." Similarly, Elder Virginia Gilbert said, “... respect, that's all we're asking." Community Forest Manager 1 agreed and described their approach to forest management decision making: "On the community forest, we don't do much work where there is so much archaeology and cultural heritage because we don't want to be disrespectful of what's there." Clearly, respect is a shared value that will continue to guide management at $\mathrm{Ne}$ Sextsine.

In the context of the proposed grassland restoration, one community forest manager reflected on how the collaborative 
experiment provided a pathway for the Elders' knowledge to guide the process: "We've got a few grasslands... that are really closely associated with First Nations values, so it's one that we want to put on the map, and these forest walks really help introduce the subject and start from there" [Manager 1]. Furthermore, as demonstrated above ("...I think you gathered that" [Elder Jean William]), the Elders had faith that the community forest managers would uphold respect and continue to provide a pathway through which both the content and context of their knowledge could guide future forest management because of the trust built through our collaborative experiment. Of the importance of this trust, Community Forest Manager 1 reflected: "I think these forest walks have helped us as a management team become known to the Elders...it's sort of an informal meeting place between [Western science and traditional ecological knowledge], and I find that really valuable."

Although the colonial context disrupted knowledge transmission for the T'exelc, visiting Ne Sextsine again as part of our collaborative experiment helped create a pathway for this context to shift toward one in which their knowledge was (re)activated and (re)connected to place, and, ideally, (re)vived the process of intergenerational knowledge exchange. Sharing his excitement at visiting $\mathrm{Ne}$ Sextsine again, Elder 7 reflected that "I was just wondering actually if I was ever going to be able to do a trip like this down to Flat Rock, and just take a look back at my younger day." Decades of restricted access to Ne Sextsine - because of gates, fences, government policy, and ongoing animosity toward the T'exelcemc - limited opportunities for Elders to pass on their knowledge to the youth of their community. Although $\mathrm{Ne}$ Sextsine became part of the Williams Lake Community Forest in 2014, access is still contested by adjacent private landowners, providing few opportunities (these forest walks being an exception) for the Elders and youth to visit. This inability to facilitate place-based, intergenerational knowledge transmission weighed heavily on the minds of Elders, exemplified by Elder Estkwelálnik's reflection on the importance of visiting $\mathrm{Ne}$ Sextsine with the youth:

We have our legends that we want to pass on from my generation to the next... There's two legends that I know that were given to me and that needs to be passed on. And those are really, really important because that's part of puberty...and how...you're brought up to respect everything that we walk on, that we see... And so that's how much it means to all of us.

One Elder lamented at only being able to share stories, rather than lived experience, with the youth in their family:

My children, I got five, ten grandchildren and four great-
grandchildren, and none of them seen Flat Rock. Except
[three of them], but my grandkids didn't. I tell them
about it and I have it written down... [but] my
grandchildren never experienced what I went through
down there [Elder Virginia Gilbert].

This inability to access their traditional territory and share both the content and context of knowledge through place-based practice with younger generations was summarized by Elder Virginia Gilbert who said they "aren't aware of our ways." Most Elders present for the forest walks indicated their desire to bring the youth out to Ne Sextsine because "our youth don't know the land...it's a different era" [Elder Jean William], demonstrating their vision for a new context for their knowledge of Ne Sextsine to thrive once again.

\section{DISCUSSION}

Through our collaborative experiment, we highlight three key considerations for understanding and incorporating situated resilience in a fire-dependent SES. First, we argue that the situated resilience concept helped illuminate the context of T'exelc fire knowledge and is highly relevant for land managers working with Indigenous communities whose content of traditional fire knowledge may be "lost." Second, we demonstrate how our collaborative experiment helped shift the context of T'exelc knowledge at Ne Sextsine away from being integrated into dominant colonial paradigms toward Indigenous-led visions of resilience. Finally, we discuss the ways in which fire-dependent SES should be conceptualized to ensure that resilience is situated to prevent inequitable solutions to modern wildfire challenges.

\section{Situating Resilience at Ne Sextsine}

Employing situated resilience helped emphasize the importance of the context of fire knowledge, centering the voices of the Elders as they shared their memories and stories of place. In this case study, the fact that the T'exelc Elders described their fire knowledge as a "lost practice" could have signaled the end of our research collaboration if this was the only knowledge deemed "appropriate" by researchers and/or managers - which would have reflected the problematic assumption by non-Indigenous researchers more broadly that fire knowledge is universal and uninterrupted (Lake 2013). To avoid this, we focused on the context of the fire knowledge, which included the extent to which colonialism disrupted place-based practices of intentional fire use, as well as the knowledge and practices that endure despite colonialism.

These altered experiences with fire as a result of colonialism are consistent with other Indigenous communities in British Columbia (Lewis et al. 2018) and around the world, including Australia and the United States of America (Eriksen and Hankins 2014, Lake and Christianson 2019), Brazil (Mistry et al. 2005), Mexico (Martínez-Torres et al. 2016), and Venezuela (Sletto 2009, Rodríguez et al. 2018). As a result of colonialism, for example, younger generations often have less experience of intentionally using fire for traditional purposes and instead tend to perceive fire control or suppression as favorable (Mistry et al. 2005, Rodríguez et al. 2018, Martínez-Torres et al. 2016). This was true even of several of the younger T'exelc Elders, who had no lived experience of intentional burning or whose experiences with intentional burning were only around their reserve (in a colonial context). Similarly, younger participants from the Lytton First Nation in a case study in the adjacent Nlaka'pamux territory recalled mostly localized burning for hazard abatement rather than for ecological benefits at landscape scales (Lewis et al. 2018).

Despite disrupted fire knowledge, the context of this knowledge also illustrated a rich and enduring connection to Ne Sextsinea critical and often overlooked context but one that provides the foundation for Indigenous-led situated resilience. For land managers and natural scientists working with Indigenous communities, respecting this context is key for overcoming the 
"invisible losses" of colonialism, such as knowledge lost when place-based intergenerational knowledge transmission can no longer occur (Turner et al. 2008). At Ne Sextsine, for example, the area of grassland restoration visited during the forest walks was initially designated through an ecological assessment based on historical aerial imagery from the 1970s (Williams Lake Community Forest Limited Partnership 2015). From the Elders' stories, however, we learned that this area was a primary travel corridor to summer fishing camps, which effectively enlarged the area of grassland restoration that needed to occur beyond the boundaries identified in the historical imagery and connected it to one of the culturally modified way marker trees. Furthermore, although the Elders did not specifically remember using fire to maintain open conditions in this area, the descriptions they provided of important plants at Ne Sextsine (Table 1) that reflected the broader context of their knowledge, in combination with evidence of past fires in tree-rings (collected as part of a complementary study to this one), helped illustrate that certain plants associated with frequent, low-severity fire, such as soapberry (Shepherdia canadensis; Walkup 1991), were primary food sources during the Elders' summer visits to Ne Sextsine. These examples illustrate how situated resilience can help land managers and natural scientists acknowledge and center Indigenous knowledge in leading forest management (Wong et al. 2020, Buxton et al. 2021).

\section{Collaborative Experiment to Shift Context}

In British Columbia, the unprecedented 2017 wildfire season illustrated the stark power asymmetry between the dominant, western command-and-control fire management paradigm and the many ways in which Indigenous peoples relate to, learn from, and live with fire in ecocultural landscapes (Miller et al. 2010, Abbott and Chapman 2018, Martínez-Torres et al. 2018). As a result of the 2017 wildfire season, many Indigenous communities worked to shift this imbalance through revitalizing their fire stewardship (Xwisten Nation et al. 2018) and Indigenous-led approaches to future fire management (Verhaeghe et al. 2019), advancing goals of restoration and reconciliation simultaneously (Dickson-Hoyle et al. 2021). At $\mathrm{Ne}$ Sextsine, by framing our research as a collaborative experiment, we also sought to address the power asymmetry (context) by centering the needs of the T'exelc Elders, essentially moving research from a positivist paradigm grounded in reductionist and empirical information (e.g., "technical fire knowledge") to a transformative paradigm focused on minimizing power inequalities between different forms of knowledge (Creswell 2014, Christianson 2015, Datta et al. 2015, Neale et al. 2019). Although we researchers acknowledge that this collaborative experiment did not actively lead to formal T'exelc authority over $\mathrm{Ne}$ Sextsine - which is the ideal place from which power over knowledge could be decolonized (Smith 2012, Midzain-Gobin and Smith 2021) - we argue that this process did help shift the context of knowledge toward a more equal balance of power between collaborators in contrast to historical processes of consultation (Usher 2000).

As reflected both by the T'exelc Elders and the community forest managers, the collaborative experiment embedded a trust-building process in which different knowledge of fire and $\mathrm{Ne}$ Sextsine could be respectfully discussed. This trust-building process is central to respectful research relationships between Indigenous and nonIndigenous actors (Datta et al. 2015, Wong et al. 2020) and has successfully been implemented in other fire contexts where Indigenous and non-Indigenous perspectives of fire were potentially contentious (Rodríguez et al. 2018, Devisscher et al. 2019, Mistry et al. 2019). Through the collaborative experiment framing, we (researchers and managers) relied on the process (rather than a checklist) of collaboration to learn from the T'exelc Elders appropriate engagement protocols (e.g., land-based knowledge exchange) and management guidelines (e.g., operating with respect for the land and ancestors) for addressing the Elders' needs. This process has successfully helped non-Indigenous researchers better understand the context of Indigenous knowledge and expose power asymmetries between Western science and Indigenous forms of knowledge in addressing complex fire management questions (Christianson 2015, Neale et al. 2019). Critically, the trust-building process helped to address the power asymmetry by centering Indigenous knowledge and knowledge systems, which rely on the process of place-based, intergenerational knowledge transmission (Turner et al. 2000). At Ne Sextsine, our collaborative experiment helped situate T'exelc resilience in a transformed context by (re)activating the Elders' enduring place-based knowledge and discussing future opportunities for forest walks with Elders and T'exelc youth. We see our collaborative experiment as a form of reflexive governance because we actively engaged with multiple, often contested, understandings of the system itself and we co-developed a process to reveal how different forms of knowledge are situated within their context (Voß and Kemp 2006, Leach et al. 2007, Rodríguez et al. 2018).

\section{Situating Indigenous Resilience in Fire-dependent Social- ecological Systems}

Against the backdrop of a much broader literature on incorporating Indigenous and Western knowledge in forest management (Nadasdy 1999, Klooster 2002, Bohensky and Maru 2011, Hill et al. 2012, Ban et al. 2018, Lake et al. 2018), here we argue that situated resilience can help ensure that incorporating Indigenous knowledge does not fall into the "knowledge integration trap" (Bohensky and Maru 2011). Instead, situated resilience helps overcome the potential "social-ecological traps" that can occur when land management authority is held in colonial systems and contested by Indigenous peoples by acknowledging the ways that colonial contexts have affected Indigenous knowledge (Long and Lake 2018). In fire-dependent SES, failure to interrogate this context will continue to privilege Western science-based knowledge and solutions (Bohensky and Maru 2011, Cote and Nightingale 2012), for example, by "subjugating" Indigenous experiences in firefighting (Eriksen and Hankins 2014) or fire management (Lake and Christianson 2019, Sherry et al. 2019). In Canada, there are increasing calls to ensure that Indigenous knowledge leads land-based decision making through appropriate research and practice (Christianson 2015, Sankey 2018), and yet fire-dependent SES do not yet adequately consider the context of this knowledge.

Several key fire SES research scholars acknowledge that Indigenous knowledge can be leveraged to develop solutions to modern wildfire management challenges (Moritz et al. 2014, Smith et al. 2016), and that Indigenous governance adds complexity to fire SES (Moritz et al. 2014). Although this is an important first step, it stops short of recognizing how Western science-based knowledge used to conceptualize fire SES may be 
discounting the context of Indigenous knowledge. Reflecting on the question posed by the advocates for situated resilience (Cote and Nightingale 2012), we must ask for whose resilience is Indigenous knowledge is being leveraged? If we situate resilience according to the context of Indigenous knowledge, for example, we may include elements such as respect and intergenerational knowledge exchange as a primary input into building resilience that reflects Indigenous ontologies and epistemologies (Turner et al. 2000, Nikolakis and Roberts 2020). Furthermore, in the context of modern wildfire challenges, the SES may be situated to include areas where we not only see fire affecting visible human "development," such as the wildland-urban interface (Moritz et al. 2014), but could be situated to include the ecocultural landscapes more broadly to which Indigenous peoples are still connected (White et al. 2011, Miller and Davidson-Hunt 2013). In these ways, we challenge land managers and fire SES thinkers to more deeply question transformational change (McWethy et al. 2019) and consider the myriad ways in which Indigenous peoples can contribute to and lead solutions to modern wildfire challenges according to their own definitions of resilience (Miller and Davidson-Hunt 2013, Christianson 2015).

Responses to this article can be read online at: https://www.ecologyandsociety.org/issues/responses. $\mathrm{php} / 12757$

\section{Acknowledgments:}

We thank the people and the places that made this research possible. First, we acknowledge that this research took place primarily on the traditional, ancestral, and unceded territory of the Texelc and the broader Secwepemcúl'ecw. Much of the analysis and writing took place on the traditional, ancestral, and unceded territory of the Musqueam peoples, on which the University of British Columbia currently sits. We are grateful to the Texelc Elders, who graciously shared their stories, wisdom, and laughter with us, including Jean William (also a Williams Lake First Nation cultural advisor), Virginia Gilbert, Millie Emile, Joan Meshue, Estkwelálnik, Edith Wycotte, Linda Narcisse, and one other Elder. We also thank the other collaborators on this research, including: the Williams Lake First Nation Natural Resources Department and Sugarcane Archaeology, especially Whitney Spearing and Brittany Cleminson, for ongoing inspiration and input; and the Williams Lake Community Forest managers (Ken Day, Hugh Flinton, and Kent Watson) for thoughtfully and carefully managing Ne Sextsine. We also appreciate the input of Spencer Bronson and Christine Copes who helped during the forest walks. Finally, we thank helpful comments from Ken Day and Jeanine Rhemtulla on an earlier version of this manuscript and the insightful comments from Amy Cardinal Christianson and two other anonymous reviewers that greatly improved this manuscript. This research was funded by the University of British Columbia (UBC) Public Scholars Initiative, $U B C$ Forestry Aboriginal Community Engagement Seed Funding, and a grant from an anonymous foundation.

\section{Data Availability:}

The data used in this study (including interview transcripts and codes) are not publicly available due to confidentiality and data ownership held by the Texelc (Williams Lake First Nation) as per the Memorandum of Understanding guiding this research. Ethical approval for this research was granted by the Texelc, outlined in the Memorandum of Understanding, and by the University of British Columbia Behavioral Research Ethics Board (H18-00779).

\section{LITERATURE CITED}

Abbott, G., and M. Chapman. 2018. Addressing the new normal: 21st century disaster management in British Columbia. Report and findings of the British Columbia Flood and Wildfire Review: an independent review examining the 2017 flood and wildfire seasons. Government of British Columbia, Victoria, British Columbia, Canada.

Adger, W. N. 2000. Social and ecological resilience: are they related? Progress in Human Geography 24(3):347-364. https:// doi.org/10.1191/030913200701540465

Agrawal, A. 1995. Dismantling the divide between Indigenous and scientific knowledge. Development and Change 26:413-439. https://doi.org/10.1111/j.1467-7660.1995.tb00560.x

Anonymous. 1879. An astonishing state of things at Williams Lake - the Natives said to be starving and threatening violence. Pathetic letter from an Indian Chief. Daily British Colonist: 7 November 1879.

Ban, N. C., A. Frid, M. Reid, B. Edgar, D. Shaw, and P. Siwallace. 2018. Incorporate Indigenous perspectives for impactful research and effective management. Nature Ecology and Evolution 2 (11):1680-1683. https://doi.org/10.1038/s41559-018-0706-0

Berkes, F. 2009. Evolution of co-management: role of knowledge generation, bridging organizations and social learning. Journal of Environmental Management 90(5):1692-1702. https://doi. org/10.1016/j.jenvman.2008.12.001

Berkes, F., J. Colding, and C. Folke, C., editors. 2003. Navigating social-ecological systems: building resilience for complexity and change. Cambridge University Press, New York, New York, USA. https://doi.org/10.1017/CBO9780511541957

Berkes, F. and C. Folke. 1998. Linking social and ecological systems: management practices and social mechanisms for building resilience. Cambridge University Press, Cambridge, UK.

Binder, C., J. Hinkel, P. Bots, and P.-W. Claudia. 2011. Comparison of frameworks for analyzing social-ecological systems. Ecology and Society 18(4): 26. https://doi.org/10.5751/ ES-05551-180426

Blythe, J., K. Nash, J. Yates, and G. Cumming. 2017. Feedbacks as a bridging concept for advancing transdisciplinary sustainability research. Current Opinion in Environmental Sustainability 26-27:114-119. https://doi.org/10.1016/j.cosust.2017.05.004

Bohensky, E. L., and Y. Maru. 2011. Indigenous knowledge, science, and resilience: what have we learned from a decade of international literature on "integration"? Ecology and Society 16 (4): 6. https://doi.org/10.5751/ES-04342-160406 
Borrows, J. 2017. Challenging historical frameworks: Aboriginal rights, the trickster, and originalism. Canadian Historical Review 98(1):114-135. https://doi.org/10.3138/chr.98.1.Borrows

Bowman, D. M. J. S., J. K. Balch, P. Artaxo, W. J. Bond, J. M. Carlson, M. A. Cochrane, C. D'Antonio, R. S. DeFries, J. C. Doyle, S. P. Harrison, F. H. Johnston, J. E. Keeley, M. A. Krawchuk, C. A. Kull, J. B. Marston, M. A. Moritz, I. C. Prentice, C. I. Roos, A. C. Scott, T. W. Swetnam, G. van der Werf, S. J. Pyne, C. M. D'Antonio, R. S. DeFries, J. C. Doyle, S. P. Harrison, F. H. Johnston, J. E. Keeley, M. A. Krawchuk, C. A. Kull, J. B. Marston, M. A. Moritz, I. C. Prentice, C. I. Roos, A. C. Scott, T. W. Swetnam, G. R. Van Der Werf, and S. J. Pyne. 2009. Fire in the earth system. Science 324(5926):481-484. https://doi.org/10.1126/ science. 1163886

Bowman, D. M. J. S., J. Balch, P. Artaxo, W. J. Bond, M. A. Cochrane, C. M. D’Antonio, R. Defries, F. H. Johnston, J. E. Keeley, M. A. Krawchuk, C. A. Kull, M. Mack, M. A. Moritz, S. Pyne, C. I. Roos, A. C. Scott, N. S. Sodhi, and T. W. Swetnam. 2011. The human dimension of fire regimes on Earth. Journal of Biogeography 38(12):2223-2236. https://doi.org/10.1111/ j.1365-2699.2011.02595.X

Boyd, R., editor. 1999. Indians, fire, and the land. Oregon State University Press, Corvallis, Oregon, USA.

British Columbia Community Forest Association (BCCFA). 2020. Community forest indicators 2020. BCCFA, Victoria, British Columbia, Canada.

Brown, K. 2014. Global environmental change I: a social turn for resilience? Progress in Human Geography 38(1):1-11. https://doi. org/10.1177/0309132513498837

Buxton, R. T., J. R. Bennett, A. J. Reid, C. Shulman, S. J. Cooke, C. M. Francis, E. A. Nyboer, G. Pritchard, A. D. Binley, S. AveryGomm, N. C. Ban, K. F. Beazley, E. Bennett, L. K. Blight, L. E. Bortolotti, A. F. Camfield, F. Gadallah, A. L. Jacob, I. Naujokaitis-Llewis, C. Raudsepp-Hearne, D. G. Roche, F. Soulard, D. Stralberg, K. D. Sadler, K. A. Solarik, C. D. Ziter, J. Brandt, C. W. Mckindsey, D. A. Greenwood, P. C. Boxall, C. F. Ngolah, K. M. A. Chan, D. Lapen, S. Poser, J. Girard, C. Dibacco, S. Hayne, D. Orihel, D. Lewis, D. Littlechild, S. J. Marshall, L. Mcdermott, R. Whitlow, D. Browne, J. Sunday, and P. A. Smith. 2021. Key information needs to move from knowledge to action for biodiversity conservation in Canada. Biological Conservation 256: 108983. https://doi.org/10.1016/j.biocon.2021.108983

Caverley, N., A. Lyall, S. Pizzirani, and J. Bulkan. 2020. Articulating Indigenous rights within the inclusive development framework: an assessment of forest stewardship policies and practices in British Columbia, Canada. Society and Natural Resources 33(1):25-45. https://doi.org/10.1080/08941920.2019.1597237

Charmaz, K. 2006. An invitation to grounded theory. Pages 1-41 in K. Charmaz. Constructing grounded theory: a practical guide through qualitative analysis. SAGE Publications Ltd, London, UK.

Christianson, A. 2015. Social science research on indigenous wildfire management in the 21 st century and future research needs. International Journal of Wildland Fire 24(2):190-200. https://doi.org/10.1071/WF13048
Cote, M., and A. J. Nightingale. 2012. Resilience thinking meets social theory: situating social change in socio-ecological systems (SES) research. Progress in Human Geography 36(4):475-489. https://doi.org/10.1177/0309132511425708

Creswell, J. W. 2013. Qualitative inquiry and research design: choosing among five approaches. Sage, Thousand Oaks, California, USA.

Creswell, J. 2014. Research design: qualitative, quantitative and mixed methods approaches. Sage, Thousand Oaks, California, USA.

Cretney, R. 2014. Resilience for whom? Emerging critical geographies of socio-ecological resilience. Geography Compass 8(9):627-640. https://doi.org/10.1111/gec3.12154

Cutter, S. L. 2016. Resilience to what? Resilience for whom? Geographical Journal 182(2):110-113. https://doi.org/10.1111/ geoj.12174

Datta, R., N. U. Khyang, H. K. Prue Khyang, H. A. Prue Kheyang, M. Ching Khyang, and J. Chapola. 2015. Participatory action research and researcher's responsibilities: an experience with an Indigenous community. International Journal of Social Research Methodology 18(6):581-599. https://doi. org/10.1080/13645579.2014.927492

Davidson-Hunt, I. J., and R. M. O'Flaherty. 2007. Researchers, Indigenous peoples, and place-based learning communities. Society and Natural Resources 20(4):291-305. https://doi. org/10.1080/08941920601161312

Devisscher, T., Y. Malhi, and E. Boyd. 2019. Deliberation for wildfire risk management: addressing conflicting views in the Chiquitania, Bolivia. Geographical Journal 185(1):38-54. https:// doi.org/10.1111/geoj.12261

Dickson-Hoyle, S., R. E. Ignace, M. B. Ignace, S. M. Hagerman, L. D. Daniels, and K. Copes-Gerbitz. 2021. Walking on two legs: a pathway of Indigenous restoration and reconciliation in fireadapted landscapes. Restoration Ecology (online early): e13566. https://doi.org/10.1111/rec.13566

Eriksen, C. 2007. Why do they burn the "bush"? Fire, rural livelihoods, and conservation in Zambia. Geographical Journal 173(3):242-256. https://doi.org/10.1111/j.1475-4959.2007.00239. $\underline{x}$

Eriksen, C., and D. L. Hankins. 2014. The retention, revival, and subjugation of Indigenous fire knowledge through agency fire fighting in eastern Australia and California. Society and Natural Resources 27(12):1288-1303. https://doi.org/10.1080/08941920.2014.918226

Fischer, A. P., T. A. Spies, T. A. Steelman, C. Moseley, B. R. Johnson, J. D. Bailey, A. A. Ager, P. Bourgeron, S. Charnley, B. M. Collins, J. D. Kline, J. E. Leahy, J. S. Littell, J. D. A. Millington, M. Nielsen-Pincus, C. S. Olsen, T. B. Paveglio, C. I. Roos, M. M. Steen-Adams, F. R. Stevens, J. Vukomanovic, E. M. White, and D. M. J. S. Bowman. 2016. Wildfire risk as a socioecological pathology. Frontiers in Ecology and the Environment 14 (5):276-284. https://doi.org/10.1002/fee.1283

Fisher, A. D., and M. Lundberg. 2015. Human rights' legitimacy in the face of the global ecological crisis-Indigenous peoples, 
ecological rights claims and the inter-American human rights system. Journal of Human Rights and the Environment 6 (2):177-203. https://doi.org/10.4337/jhre.2015.02.03

Folke, C. 2016. Resilience (republished). Ecology and Society 21 (4): 44. https://doi.org/10.5751/ES-09088-210444

Folke, C., S. R. Carpenter, B. Walker, M. Scheffer, T. Chapin, and J. Rockström. 2010. Resilience thinking: integrating resilience, adaptability and transformability. Ecology and Society 15(4): 20. https://doi.org/10.5751/ES-03610-150420

Gottesfeld, L. M. 1994. Aboriginal burning for vegetation management in northwest British Columbia. Human Ecology 22 (2):171-188. https://doi.org/10.1007/BF02169038

Hanes, C. C., X. Wang, P. Jain, M. Parisien, J. M. Little, and M. D. Flannigan. 2019. Fire-regime changes in Canada over the last half century. Canadian Journal of Forest Research 269:256-269. https://doi.org/10.1139/cjfr-2018-0293

Higuera, P. E., A. L. Metcalf, C. Miller, B. Buma, D. B. Mcwethy, E. C. Metcalf, Z. A. K. Ratajczak, C. R. Nelson, B. C. Chaffin, R. C. Stedman, S. Mccaffrey, T. Schoennagel, B. J. Harvey, S. M. Hood, C. A. Schultz, A. E. Black, D. Campbell, J. H. Haggerty, R. E. Keane, M. E. G. A. Krawchuk, J. C. Kulig, R. Rafferty, and A. Virapongse. 2019. Integrating subjective and objective dimensions of resilience in fire-prone landscapes. BioScience 69 (5):379-388. https://doi.org/10.1093/biosci/biz030

Hill, R., C. Grant, M. George, C. J. Robinson, S. Jackson, and N. Abel. 2012. A typology of Indigenous engagement in Australian environmental management. Ecology and Society 17(1): 23. https://doi.org/10.5751/ES-04587-170123

Holling, C. S., and G. K. Meffe. 1996. Command and control and the pathology of natural resource management. Conservation Biology 10(2):328-337. https://doi.org/10.1046/j.1523-1739.1996.10020328. $\underline{x}$

Houde, N. 2007. The six faces of traditional ecological knowledge: challenges and opportunities for Canadian co-management arrangements. Ecology and Society 12(2):34. https://doi. org/10.5751/ES-02270-120234

Huffman, M. R. 2013. The many elements of traditional fire knowledge: synthesis, classification, and aids to cross-cultural problem solving in fire dependent systems around the world. Ecology and Society 18(4): 3. https://doi.org/10.5751/ ES-05843-180403

Ignace, M., and R. Ignace, editors. 2019. Secwépemc people, land and laws (Yerí7 re Stsqeýs-kucw). McGill-Queen's University Press, Montreal, Quebec, Canada.

Ignace, M., N. J. Turner, and S. L. Peacock, editors. 2016. Secwepemc people and plants: research papers in Shuswap ethnobotany. Contributions in Ethnobiology, Society of Ethnobiology, Boston, Massachusetts, USA.

Ingalls, M. L., and R. C. Stedman. 2016. The power problematic: exploring the uncertain terrains of political ecology and the resilience framework. Ecology and Society 21(1): 6. https://doi. org/10.5751/ES-08124-210106
Klooster, D. J. 2002. Toward adaptive community forest management: integrating local forest knowledge with scientific forestry. Economic Geography 78(1): 43. https://doi.org/10.2307/4140823

Krebs, P., G. B. Pezzatti, S. Mazzoleni, L. M. Talbot, and M. Conedera. 2010. Fire regime: history and definition of a key concept in disturbance ecology. Theory in Biosciences 129 (1):53-69. https://doi.org/10.1007/s12064-010-0082-z

Lake, F. K. 2013. Historical and cultural fires, tribal management and research issue in northern California: trails, fires and tribulations. Occasion: Interdisciplinary Studies in the Humanities 5(2012):1-22.

Lake, F. K., and A. C. Christianson. 2019. Indigenous fire stewardship. Pages 1-9 in S. L. Manzello, editor. Encyclopedia of Wildfires and Wildland-Urban Interface (WUI) Fires, Springer, Dordrecht, The Netherlands. https://doi.org/10.1007/978-3-319$-51727-8 \quad 225-1$

Lake, F. K., J. Parrotta, C. P. Giardina, I. Davidson-Hunt, and Y. Uprety. 2018. Integration of traditional and western knowledge in forest landscape restoration. Pages 198-226 in S. Mansourian and J. Parrotta, editors. Forest landscape restoration: integrated approaches to support effective implementation. Routledge, New York, New York, USA. https://doi.org/10.4324/9781315111872-12

Lake, F. K., V. Wright, P. Morgan, M. McFadzen, D. McWethy, and C. Stevens-Rumann. 2017. Returning fire to the land: celebrating traditional knowledge and fire. Journal of Forestry 115(5):343-353. https://doi.org/10.5849/jof.2016-043R2

Leach, M., G. Bloom, A. Ely, P. Nightingale, I. Scoones, E. Shah, and A. Smith. 2007. Understanding governance: pathways to sustainability. Social, Technological and Environmental Pathways to Sustainability (STEPS) Centre, Brighton, UK.

Lewis, H. T. 1982. A time for burning. Occasional Publication 17, Boreal Institute for Northern Studies, University of Alberta, Edmonton, Alberta, Canada.

Lewis, M., A. Christianson, and M. Spinks. 2018. Return to flame: reasons for burning in Lytton First Nation, British Columbia. Journal of Forestry 116(2):143-150. https://doi.org/10.1093/ jofore/fvx007

Liu, J., T. Dietz, S. R. Carpenter, M. Alberti, C. Folke, E. Moran, A. N. Pell, P. Deadman, T. Kratz, J. Lubchenco, E. Ostrom, Z. Ouyang, W. Provencher, C. L. Redman, S. H. Schneider, and W. W. Taylor. 2007. Complexity of coupled human and natural systems. Science 317(5844):1513-1516. https://doi.org/10.1126/ science. 1144004

Long, J. W., and F. K. Lake. 2018. Escaping social-ecological traps through tribal stewardship on national forest lands in the Pacific Northwest, United States of America. Ecology and Society 23(2): 10. https://doi.org/10.5751/ES-10041-230210

Martínez-Torres, H. L., A. Castillo, M. I. Ramírez, and D. R. Pérez-Salicrup. 2016. The importance of the traditional fire knowledge system in a subtropical montane socio-ecosystem in a protected natural area. International Journal of Wildland Fire 25(9):911-921. https://doi.org/10.1071/WF15181 
Martínez-Torres, H. L., D. R. Pérez-Salicrup, A. Castillo, and M. I. Ramírez. 2018. Fire management in a natural protected area: what do key local actors say? Human Ecology 46(4):515-528. https://doi.org/10.1007/s10745-018-0013-Z

McGee, T. K., M. O. Nation, and A. C. Christianson. 2019. Residents' wildfire evacuation actions in Mishkeegogamang Ojibway Nation, Ontario, Canada. International Journal of Disaster Risk Reduction 33:266-274. https://doi.org/10.1016/j. ijdrr.2018.10.012

McGinnis, M. D., and E. Ostrom. 2014. Social-ecological system framework: initial changes and continuing. Ecology and Society 19(2): 30. https://doi.org/10.5751/ES-06387-190230

McWethy, D. B., T. Schoennagel, P. E. Higuera, M. Krawchuk, B. J. Harvey, E. C. Metcalf, C. Schultz, C. Miller, A. L. Metcalf, B. Buma, A. Virapongse, J. C. Kulig, R. C. Stedman, Z. Ratajczak, C. R. Nelson, and C. Kolden. 2019. Rethinking resilience to wildfire. Nature Sustainability 2(9):797-804. https://doi. org/10.1038/s41893-019-0353-8

Midzain-Gobin, L., and H. A. Smith. 2021. Debunking the myth of Canada as a non-colonial power. American Review of Canadian Studies 50(4):479-497. https://doi.org/10.1080/02722011.2020 .1849329

Miller, A. M., and I. Davidson-Hunt. 2013. Agency and resilience: teachings of Pikangikum First Nation elders, northwestern Ontario. Ecology and Society 18(3): 9. https://doi.org/10.5751/ ES-05665-180309

Miller, A. M., I. J. Davidson-Hunt, and P. Peters. 2010. Talking about fire: Pikangikum First Nation elders guiding fire management. Canadian Journal of Forest Research 40 (12):2290-2301. https://doi.org/10.1139/X10-177

Mistry, J., A. Berardi, V. Andrade, T. Kraho, P. Kraho, and O. Leonardos. 2005. Indigenous fire management in the cerrado of Brazil: the case of the Krahô of Tocantíns. Human Ecology 33 (3):365-386. https://doi.org/10.1007/s 10745-005-4143-8

Mistry, J., I. B. Schmidt, L. Eloy, and B. Bilbao. 2019. New perspectives in fire management in South American savannas: the importance of intercultural governance. Ambio 48(2):172-179. https://doi.org/10.1007/s13280-018-1054-7

Moritz, M. A., E. Batllori, R. A. Bradstock, A. M. Gill, J. Handmer, P. F. Hessburg, J. Leonard, S. McCaffrey, D. C. Odion, T. Schoennagel, and A. D. Syphard. 2014. Learning to coexist with wildfire. Nature 515(7525):58-66. https://doi.org/10.1038/ $\underline{\text { nature } 13946}$

Nadasdy, P. 1999. The politics of TEK: power and the "integration" of knowledge. Arctic Anthropology 36(1-2):1-18.

Neale, T., R. Carter, T. Nelson, and M. Bourke. 2019. Walking together: a decolonising experiment in bushfire management on Dja Dja Wurrung country. Cultural Geographies 26(3):341-359. https://doi.org/10.1177/1474474018821419

Nikolakis, W., and E. Roberts. 2020. Indigenous fire management: a conceptual model. Ecology and Society 25(4): 11. https://doi. org/10.5751/ES-11945-250411
Ostrom, E. 2009. A general framework for analyzing sustainability of social-ecological systems. Science 325 (5939):419-422. https://doi.org/10.1126/science.1172133

Pelai, R., S. M. Hagerman, and R. Kozak. 2021. Seeds of change? Seed transfer governance in British Columbia: insights from history. Canadian Journal of Forest Research 51(2):326-338. https://doi.org/10.1139/cjfr-2020-0235

Pierotti, R., and D. Wildcat. 2000. Traditional ecological knowledge: the third alternative (commentary). Ecological Applications 10(5):1333-1340. https://doi.org/10.1890/1051-0761 (2000)010[1333:TEKTTA]2.0.CO;2

Rodríguez, I., B. Sletto, B. Bilbao, I. Sánchez-Rose, and A. Leal. 2018. Speaking of fire: reflexive governance in landscapes of social change and shifting local identities. Journal of Environmental Policy and Planning 20(6):689-703. https://doi. org/10.1080/1523908X.2013.766579

Roos, C. I., D. M. J. S. Bowman, J. K. Balch, P. Artaxo, W. J. Bond, M. Cochrane, C. M. D'Antonio, R. Defries, M. Mack, F. H. Johnston, M. A. Krawchuk, C. A. Kull, M. A. Moritz, S. Pyne, A. C. Scott, and T. W. Swetnam. 2014. Pyrogeography, historical ecology, and the human dimensions of fire regimes. Journal of Biogeography 41(4):833-836. https://doi.org/10.1111/jbi.12285

Sankey, S., technical coordinator. 2018. Blueprint for wildland fire science in Canada (2019-2029). Natural Resources Canada, Canadian Forest Service - Northern Forestry Centre, Edmonton, Alberta, Canada.

Sherry, J., T. Neale, T. K. McGee, and M. Sharpe. 2019. Rethinking the maps: a case study of knowledge incorporation in Canadian wildfire risk management and planning. Journal of Environmental Management 234:494-502. https://doi.org/10.1016/ j.jenvman.2018.12.116

Simpson, L. B. 2017. Land as pedagogy. As we have always done: Indigenous freedom through radical resistance. University of Minnesota Press, Minneapolis, Minnesota, USA. https://doi. org/10.5749/j.ctt1pwt77c.12

Sletto, B. 2009. "Indigenous people don't have boundaries": reborderings, fire management, and productions of authenticities in indigenous landscapes. Cultural Geographies 16:253-277. https://doi.org/10.1177/1474474008101519

Smith, A. M. S. S., C. A. Kolden, T. B. Paveglio, M. A. Cochrane, D. M. J. S. J. S. Bowman, M. A. Moritz, A. D. Kliskey, L. Alessa, A. T. Hudak, C. M. Hoffman, J. A. Lutz, L. P. Queen, S. J. Goetz, P. E. Higuera, L. Boschetti, M. Flannigan, K. M. Yedinak, A. C. Watts, E. K. Strand, J. W. van Wagtendonk, J. W. Anderson, B. J. Stocks, and J. T. Abatzoglou. 2016. The science of firescapes: achieving fire-resilient communities. BioScience 66(2):130-146. https://doi.org/10.1093/biosci/biv182

Smith, C., and J. Mistry. 2021. LIFE: Database of subsistenceoriented and smallholder fire use and mitigation. Royal Holloway, University of London, London, UK. https://doi.org/10.17637/rh. c.5469993.v1

Smith, L. T. 2012. Research through imperial eyes. Pages 44-60 in L. T. Smith. Decolonizing methodologies: research and Indigenous peoples. Zed Books, New York, New York, USA. 
Spies, T. A., E. M. White, J. D. Kline, A. P. Fischer, A. Ager, J. Bailey, J. Bolte, and J. Koch. 2014. Examining fire-prone forest landscapes as coupled human and natural systems. Ecology and Society 19(3): 9. https://doi.org/10.5751/ES-06584-190309

Steelman, T. 2016. U.S. wildfire governance as social-ecological problem. Ecology and Society 21(4). https://doi.org/10.5751/ ES-08681-210403

Stephens, S. L., J. K. Agee, P. Z. Fulé, M. P. North, W. H. Romme, T. W. Swetnam, and M. G. Turner. 2013. Managing forests and fire in changing climates. Science 342(6154):41-42. https://doi. org/10.1126/science.1240294

Stephens, S. L., N. Burrows, A. Buyantuyev, R. W. Gray, R. E. Keane, R. Kubian, S. Liu, F. Seijo, L. Shu, K. G. Tolhurst, J. W. van Wagtendonk, and J. W. van Wagtendonk. 2014. Temperate and boreal forest mega-fires: characteristics and challenges. Frontiers in Ecology and the Environment 12(2):115-122. https:// doi.org/10.1890/120332

Stone-Jovicich, S., B. E. Goldstein, K. Brown, R. Plummer, and P. Olsson. 2018. Expanding the contribution of the social sciences to social-ecological resilience research. Ecology and Society 23 (1): 41. https://doi.org/10.5751/ES-10008-230141

Sultana, F. 2007. Reflexivity, positionality and participatory ethics: negotiating fieldwork dilemmas in international research. ACME 6(3):374-385.

Tengö, M., E. S. Brondizio, T. Elmqvist, P. Malmer, and M. Spierenburg. 2014. Connecting diverse knowledge systems for enhanced ecosystem governance: the multiple evidence base approach. Ambio 43(5):579-591. https://doi.org/10.1007/ s13280-014-0501-3

Traditional Land Use Team of the Williams Lake Indian Band. 1998. Final report for the Williams Lake Indian Band Traditional Use Study. Williams Lake, British Columbia, Canada.

Truth and Reconciliation Commission of Canada, 2012. 2015. Truth and Reconciliation Commission of Canada: calls to action. Truth and Reconciliation Commission of Canada, Winnipeg, Manitoba, Canada.

Turner, N. J., R. Gregory, C. Brooks, L. Failing, and T. Satterfield. 2008. From invisibility to transparency: identifying the implications. Ecology and Society 13(2): 7. https://doi. org/10.5751/ES-02405-130207

Turner, N. J., M. B. Ignace, and R. Ignace. 2000. Traditional ecological knowledge and wisdom of aboriginal peoples in British Columbia. Ecological Applications 10(5):1275-1287. https://doi. org/10.1890/1051-0761(2000)010[1275:TEKAWO]2.0.CO:2

Usher, P. J. 2000. Traditional ecological knowledge in environmental assessment and management. Arctic 53 (2):183-193. https://doi.org/10.14430/arctic849

Velasquez Runk, J. 2014. Enriching Indigenous knowledge scholarship via collaborative methodologies: beyond the high tide's few hours. Ecology and Society 19(4): 37. https://doi. org/10.5751/ES-06773-190437

Verhaeghe, C., E. Feltes, and J. Stacey. 2019. Nagwedizk'an Gwanes Gangu Ch'inidzed: the fire awakened us. Tsilhqot'in
National Government, Williams Lake, British Columbia, Canada.

Voß, J. P., and R. Kemp. 2006. Sustainability and reflexive governance: introduction. Pages 3-28 in J. P. Voß, D. Bauknecht, and R. Kemp, editors. Reflexive governance for sustainable development. Edward Elgar, Cheltenham, UK. https://doi. org/10.4337/9781847200266

Walker, B., and D. Salt. 2006. Resilience thinking: sustaining ecosystems and people in a changing world. Island Press, Washington, D.C., USA.

Walkup, C. J. 1991. Shepherdia canadensis. Fire Effects Information System. U.S. Department of Agriculture, Forest Service, Rocky Mountain Research Station, Fire Sciences Laboratory, Fort Collins, Colorado, USA. [online] URL: https:// www.fs.fed.us/database/feis/plants/shrub/shecan/all.html

White, C. A., D. D. B. Perrakis, V. G. Kafka, and T. Ennis. 2011. Burning at the edge: integrating biophysical and eco-cultural fire processes in Canada's parks and protected areas. Fire Ecology 7 (1):74-106. https://doi.org/10.4996/fireecology.0701074

Williams Lake Community Forest Limited Partnership. 2015. WLCF forest stewardship plan. Williams Lake Community Forest, Williams Lake, British Columbia, Canada.

Wilson, K. 2019. Pulling together: a guide for Indigenization of post-secondary institutions. Kemampuan Koneksi Matematis (Tinjauan Terhadap Pendekatan Pembelajaran Savi). Foundations Guide, British Columbia Institute of Technology, BCcampus, Victoria, British Columbia, Canada.

Wong, C., K. Ballegooyen, L. Ignace, M. J. (Gùdia) Johnson, and H. Swanson. 2020. Towards reconciliation: 10 calls to action to natural scientists working in Canada. Facets 5(1):769-783. https:// doi.org/10.1139/facets-2020-0005

Xwisten Nation, A. C. Christianson, D. Andrew, N. Caverley, and J. Eustache. 2018. Burn plan framework development: reestablishing Indigenous cultural burning practices to mitigate risk from wildfire and drought. Canadian Institute of Forestry, Mattawa, Ontario, Canada. 